\title{
CORRELATION BETWEEN OBJECTIVE AND SUBJECTIVE ACOUSTIC QUALITY PARAMETERS OF PROFESSIONAL SOUND CONTROL ROOMS
}

\author{
Marin Milković, Miljenko Krhen, Siniša Fajt
}

Original scientific paper

Various studies performed so far have not provided unique answers to the acoustic quality evaluation of the sound control rooms, as no influence of specific features of the respective sound control room have been taken into account. In a process described in this paper, all the specific features that these rooms have are taken into consideration and sound is evaluated by means of reproduction through high quality professional equipment. Also, a listening area is a small, exactly given place for optimal listening for sound control engineer.The optimal sound control room must provide a complete and clear perception of reproduced sound with all specific features, and the room's spatial characteristics may not influence nor change the characteristics of the reproduced sound. Conjoint Analisys method is used to obtain estimation of the impact of the room objective acoustic quality parameters on the subjective assessment of the professional sound control room. Thereby, the use of modern statistical method (Conjoint Analysis - CA) shows dependence of one subjective parameter on more than one objective parameter. This principle determines more accurately real-life conditions, where all ratings are subject to complex dependence on more objective parameters.

Keywords: acoustics; acoustic quality; conjoint analysis; professional sound control room; analytical method; objective and subjective parameters

Korelacija između objektivnih i subjektivnih parametara akustičke kvalitete profesionalnih tonskih režija

Izvorni znanstveni članak

Brojne provedene analize ne daju jedinstveni odgovor na pitanje ocjene akustičke kvalitete tonskih režija, budući da nisu uvijek uzete u obzir sve karakteristike specifične za tonske režije. U procesu opisanom u ovom radu sve su specifične karakteristike uzete u obzir. Reprodukcija zvuka je provedena visokokvalitetnom profesionalnom opremom. Promatrano je točno određeno optimalno područje za slušanje. Optimalna tonska režija mora omogućiti reprodukciju zvuka sa svim njegovim karakteristikama, a karakteristike samog prostora ne smiju utjecati niti mijenjati karakteristiku reproduciranog zvuka. Združena analiza parametara je korištena za procjenu utjecaja vrijednosti objektivnih parametara akustičke kvalitete na subjektivnu procjenu. Ova moderna statistička metoda pokazuje ovisnost jednog subjektivnog parametra akustičke kvalitete o više objektivnih parametara. Taj princip bolje određuje stvarne uvjete, u kojima je svaka subjektivna ocjena složeno zavisna o više objektivnih parametara akustičke kvalitete tonskih režija.

Ključne riječi: akustika; akustička kvaliteta; združena analiza parametara; profesionalna tonska režija; analitička metoda; objektivni i subjektivni parametri

\section{Introduction}

When assessing the impact of objective parameters of the room acoustic quality on the subjective assessment, a mutual dependence of objective and subjective parameters presents a major problem which needs to be resolved. Also a very large number of objective and subjective mutually dependent parameters exists which additionally complicate the assessment process. If we assume to apply a matrix with the values of objective parameters as $[\boldsymbol{X}]$, and other matrix values of subjective rating as $[\boldsymbol{Y}]$, we can assume that there is mutual linear dependence of these two matrices as follows:

$$
[\boldsymbol{Y}]=[k] *[\boldsymbol{X}] .
$$

Unfortunately, the classical and simplified mathematical operations cannot be applied to calculate coefficient matrix $[k]$ as the quotient of matrix $[\boldsymbol{Y}]$ and $[X]$, i.e.

$$
[k] \neq \frac{[\boldsymbol{Y}]}{[\boldsymbol{X}]} .
$$

Conjoint Analysis (CA) $[1 \div 3]$ is a statistical tool that shows which real, objective parameters of a tested system have the greatest impact on the final subjective assessment or subjective decision in the quality assessment process of the tested system $[4,5]$.
In this research, CA method is used to obtain estimates of the impact of objective parameters of the room acoustic quality on the subjective assessment of the room acoustical quality parameters.

Research and analysis of objective and subjective parameters of the room acoustic quality are carried out for a total of six radio sound control rooms of Croatian Radiotelevision (Prisavlje 3, 10000 Zagreb, Croatia), as follows:

- Sound Control Room R1 and R4 - multichannel music control room

- $\quad$ Sound Control Room R5 - speech and music control room

- $\quad$ Sound Control Room R13 - control room for audio editing

- Sound Control Room R11 - large control room of "Studio Bajsić"

- Sound Control Room R12 - small control room of "Studio Bajsić".

Listed professional sound control rooms have a floor area from a minimal $25,9 \mathrm{~m}^{2}$ to a maximal $46,20 \mathrm{~m}^{2}$, with a corresponding volume of at least $75,11 \mathrm{~m}^{3}$ to a maximum of $157,08 \mathrm{~m}^{3}$, which is consistent with standardized sizes of an average professional sound control rooms. All sound control rooms are appropriately acoustically treated, i.e. walls are installed to block an outside noise, control rooms are separated from the studio area with a window and equipped with special doors that meet the needs of acoustic insulation from outside noise. In each room a mixing console is placed on the best 
listening position, and sound is radiated through professional loudspeaker systems. This opportunity was used to explore the features of the sound control rooms which are used for a longer time by a certain group of audio professionals, who are thus very familiar with their good and bad characteristics.

\section{Analysis of subjective parameters of professional sound control rooms}

Subjective assessments are carried out using a questionnaire consisting of 18 questions, whereas the last question provides the answer regarding an overall acoustic impression of the room. Subjective assessments are provided by the professionals who are engaged in processing and sound production, as well as professionals who are, with their knowledge and education, familiar with the problems of room acoustic quality and quality of the listening process.

Subjective assessments have been done by using always the same predefined and calibrated conditions as follows: sound pressure level of frequency $1 \mathrm{kHz}$ was $90 \mathrm{~dB}$ at a distance of $1 \mathrm{~m}$ from the monitor speaker in its central axis $[6 \div 9]$.

Respondents providing subjective assessments of professional sound control room listened for a total time of $16.5 \mathrm{~min}$ to specially prepared musical, which covers all areas essential to achieve the most accurate subjective assessment of the room. Selected sound samples have sharp final cuts in order to ensure better hearing perception of sound control room acoustic characteristics.

Marks used in the questionnaire are discrete in the range of 1 to 5 , where 1 is the worst and 5 is the best score. It is taken into account that in some cases the extreme marks (bad or worst) can be assessed for the same parameter for different listening results. For example, the reverberation time can be rated poor in the case when it is too big, and also in the case when it is too small. Similarly, the volume of music can be bad even if it is too loud, or too quiet, or silent. In such cases, the best marks are assessed in the case of optimum reverberation time, or optimum sound pressure level. In the case of uniquely assigned grades, as it is in the case of dynamics, descriptive marks are uniquely assigned to numerical values, for example the best mark is assigned for dynamics in the case of the highest dynamics.

The above defined ruled are applied to obtain subjective assessments of 18 parameters for all sound control rooms in which the objective parameters of acoustic quality were measured $[10,11]$

The range for each parameter in the assessed sound control room varies from minimum value 1 , which is indeed a rare case, but however exists, to maximum value 5. However, the mark 1 could be considered as a limit value case and therefore be rejected in the analysis, But for the purpose of this research, the limit marks are taken into account and analyses are made with all assessments, without rejection of the limit value cases $[12 \div 15]$.

Based on those results the rank of assessed sound control rooms for each of the parameters of subjective assessments is made, shown in Tab. 1. For the ranking of the sound control room an algorithm is designed and implemented. First, the actual value of the parameter is considered to be used for ranking. If there is more than one room with the same value, the second parameter being considered is the total acoustic impression. The rooms are then ranked within the same value of currently observed parameter by the value of the overall acoustic impression. If again there is more than one room with the same value of the observed parameter, and the same value of the overall acoustic quality, the average value of all parameters is considered, and rooms are ranked accordingly. Finally, if there is still more than one room with identical values for all above mentioned parameters for ranking, the score of grades 5, 4 and 3 are considered, and the rooms are ranked accordingly. After applying such a ranking procedure, no more than one sound control room has the same rank position.

Table 1 The highest rated sound control rooms

\begin{tabular}{|l|l|}
\hline & Top Rated Room \\
\hline Audibility of Secondary Sources & R4 \\
\hline Dynamics & R11 \\
\hline Noise volume & R11 \\
\hline Signal volume & R1 \\
\hline Intimacy (Presence) & R13 \\
\hline Distortion & R11 \\
\hline Stability of performance & R11 \\
\hline Revereberance & R11 \\
\hline Sound Definition, Clarity, & R1 \\
\hline Speech Intelligibility & R11 \\
\hline $\begin{array}{l}\text { Ambience Reproduction, Spaciosness, } \\
\text { Spatial Impresion, Diffusion }\end{array}$ & $\mathrm{R} 4$ \\
\hline Bass reproduction & R11 \\
\hline Tonal Reproduction, Timbre & R11 \\
\hline Brilliance & R1 \\
\hline Echo Disturbance & R11 \\
\hline Spectral Uniformity, Balance & R11 \\
\hline Overall Acoustic Impression & R11 \\
\hline Sound Stage Imaging & R1 \\
\hline
\end{tabular}

\section{Assessing the impact of objective parameters of the room acoustic quality on the subjective rating}

For the purpose of assessing the impact of objective parameters of the room acoustic quality on the subjective rating, six orthogonal matrices with certain objective parameters of acoustic quality and their actual measured values are first defined. According to the limitation of the method which requires a larger number of possible combinations of parameters, and their subjective evaluation and ranking, the matrices are made with objective parameters observed for impact. The combinations are shown in Tab. 2. Combinations which correspond to each other and correlate (reverberation time, clarity, IACC), or correspond chronologically to physical phenomena are selected.

Table 2 Objective parameters used for creating matrices OrtMat_01 to OrtMat 06 for analysis

\begin{tabular}{|l|l|l|l|l|l|}
\hline OrtMat_01 & EDT & $\mathrm{RT}_{10}$ & $\mathrm{RT}_{20}$ & $\mathrm{RT}_{30}$ & \\
\hline OrtMat_02 & $\mathrm{C}_{7}$ & $\mathrm{C}_{50}$ & $\mathrm{C}_{80}$ & $\mathrm{C}_{35}$ & \\
\hline OrtMat_03 & $\mathrm{EDT}$ & $\mathrm{RT}_{10}$ & $\mathrm{C}_{7}$ & $\mathrm{C}_{35}$ & $\mathrm{D}$ \\
\hline OrtMat_04 & $\mathrm{EDT}$ & $\mathrm{RT}_{30}$ & $\mathrm{C}_{50}$ & $\mathrm{C}_{80}$ & $\mathrm{D}$ \\
\hline OrtMat_05 & EDT & $\mathrm{C}_{7}$ & $\mathrm{C}_{50}$ & $\mathrm{C}_{80}$ & $\mathrm{D}$ \\
\hline OrtMat_06 & $\mathrm{IACC}_{\text {Early }}$ & $\mathrm{IACC}_{\text {Late }}$ & $\mathrm{IACC}_{\text {Full }}$ & & \\
\hline
\end{tabular}


Matrix OrtMat_01 contains the values of objective parameters related only to the reverberation time i.e. to the sound pressure decrease time, after sound source ceased emitting, with parameters measured at various intervals as follows: EDT (Early Decay Time) - time required for sound pressure to decrease from $0 \mathrm{~dB}$ to $30 \mathrm{~dB}$ extrapolated to a decrease of $60 \mathrm{~dB}$; reverberation time $\mathrm{RT}_{10}$ - time required for sound pressure to decrease from $-5 \mathrm{~dB}$ to $-15 \mathrm{~dB}$ extrapolated to a decrease of 60 $\mathrm{dB}, \mathrm{RT}_{20}$ - time required for sound pressure to decrease from $-5 \mathrm{~dB}$ to $-25 \mathrm{~dB}$ extrapolated to a decrease of 60 $\mathrm{dB}$, and $\mathrm{RT}_{30}$ - time required for sound pressure to decrease from $-5 \mathrm{~dB}$ to $-35 \mathrm{~dB}$ extrapolated to a decrease of $60 \mathrm{~dB}$. The analysis with this matrix shows dependence of all subjective assessment on different intervals that are used for estimating and calculating the reverberation time.

Matrix OrtMat 02 contains only the values of objective parameters related to the parameter Clarity, again measured with various time intervals. The usual limits of integration for calculating the parameter Clarity are taken: $50 \mathrm{~ms}$ for $\mathrm{C}_{50}$ and $80 \mathrm{~ms}$ for $\mathrm{C}_{80}$, but there are further limits taken - limits of $7 \mathrm{~ms}$ for $\mathrm{C}_{7}$ and $35 \mathrm{~ms}$ for $\mathrm{C}_{35}$. Due to the shorter integration limits time of only 7 $\mathrm{ms}$, the impact of direct sound is primarily obtained. Other limit is $35 \mathrm{~ms}$ (also below commonly used value), which is still a limit that gives us information primarily about the relationship between direct sound and all other reflections. The analysis with this matrix shows dependence of all subjective assessment on different values of parameter Clarity.

Matrix OrtMat_03 contains a combination of parameters related to the reverberation time, EDT and $\mathrm{RT}_{10}$, the parameter Clarity $\mathrm{C}_{7}$ and $\mathrm{C}_{35}$, and the parameter Definition. The impact of objective parameters of acoustical quality on the subjective assessment is observed for a short time, which gives the major influence of the direct sound.

Matrix OrtMat_04 contains the same parameters as OrtMat_03, i.e. the parameters of reverberation time, Clarity and Definition, but with different limits of integration and interval for reverberation time calculation, which provides the parameters of reverberation time EDT and $\mathrm{RT}_{30}$, and Clarity $\mathrm{C}_{50}$ and $\mathrm{C}_{80}$.

Matrix OrtMat_05 contains only one parameter related to the reverberation time, and it is EDT. Impact analysis on the subjective assessment was performed for the parameter Clarity $\mathrm{C}_{7}, \mathrm{C}_{50}$ and $\mathrm{C}_{80}$, and parameter Definition. Impact analysis of these parameters gives a more accurate overview of impact of energy parameters Clarity and Definition than the reverberation time. Parameter EDT's purpose in this analysis is to obtain the dependence of subjective assessments on the above mentioned parameters in matrix OrtMat_05, from which at least one parameter is related to reverberation time.

Matrix OrtMat_06 contains only parameters related to the measurement with the artificial head, i.e. the following parameters which determine the symmetry of the analyzed room: interaural cross-correlation index $\mathrm{IACC}_{\text {Early }}$ with limits of time integration from $0 \mathrm{~ms}$ to $80 \mathrm{~ms}, \mathrm{IACC}_{\mathrm{Late}}$ with limits of time integration from 80 $\mathrm{ms}$ to $500 \mathrm{~ms}$ and $\mathrm{IACC}_{\text {Full }}$ with limits of time integration from $0 \mathrm{~ms}$ to $500 \mathrm{~ms}$. Their statistical analysis provides the dependence of subjective assessments for each parameter of acoustic quality on the interaural crosscorrelation index, i.e. the symmetry of the tested room.

The most accurate measured values of all objective parameters of acoustic quality were selected to perform the analysis. For all values of the parameters related to the reverberation time (EDT, $\mathrm{RT}_{10}, \mathrm{RT}_{20}$ i $\left.\mathrm{RT}_{30}\right)$, Clarity $\left(\mathrm{C}_{7}\right.$, $\mathrm{C}_{50}, \mathrm{C}_{80} \mathrm{i}_{35}$ ) and Definition D, results are selected in the frequency range from $500 \mathrm{~Hz}$ to $4 \mathrm{kHz}$. Since all the examined rooms are sound control rooms designed to record speech and music, with an emphasis on tonal part, this frequency range is selected because it is most relevant for speech and music.

Values for interaural cross-correlation index $\mathrm{IACC}_{\text {Early }}$, IACC $\mathrm{Late}_{\text {ate }}$ and $\mathrm{IACC}_{\text {Full }}$ are chosen for the frequency of $1 \mathrm{kHz}$.

Creation of orthogonal matrices OrtMat_01 to OrtMat_06 always generates combinations whose number is larger than number of combinations obtained during the research, so the number of records in each matrix is determined by the total number of analyzed sound control rooms, which is six. That is, the analysis was carried out with six tracks which always contained the real value of each of the tested parameters and their actual combination, measured for each sound control room [16].

Impact coefficients of selected objective parameters on the subjective assessment of acoustical quality of sound control rooms are presented.

\subsection{The impact coefficients of objective parameters EDT, $\mathrm{RT}_{10}, \mathrm{RT}_{20}$ and $\mathrm{RT}_{30}$ on the values of subjective parameters of acoustical quality}

Table 3 The impact coefficients EDT, $\mathrm{RT}_{10}, \mathrm{RT}_{20}$ and $\mathrm{RT}_{30}$ on subjective assessments

\begin{tabular}{|l|r|r|r|r|}
\hline & $\mathrm{EDT}$ & $\mathrm{RT}_{10}$ & $\mathrm{RT}_{20}$ & $\mathrm{RT}_{30}$ \\
\hline $\begin{array}{l}\text { Audibility of Secondary } \\
\text { Sources }\end{array}$ & 10,6 & 19,2 & 36,6 & 33,7 \\
\hline Dynamics & 19,9 & 15,8 & 25,8 & 38,5 \\
\hline Noise volume & 23,0 & 16,0 & 24,1 & 36,9 \\
\hline Signal volume & 18,5 & 21,2 & 34,4 & 25,9 \\
\hline Intimacy (Presence) & 14,2 & 24,9 & 27,3 & 33,6 \\
\hline Distortion & 29,6 & 16,4 & 24,1 & 30,0 \\
\hline Stability of performance & 12,2 & 24,6 & 30,9 & 32,3 \\
\hline Revereberance & 12,9 & 24,8 & 33,4 & 28,8 \\
\hline Sound Definition, Clarity & 16,8 & 18,0 & 25,2 & 40,0 \\
\hline Speech Intelligibility & 22,2 & 25,8 & 24,9 & 27,1 \\
\hline $\begin{array}{l}\text { Ambience Reproduction, } \\
\text { Spaciosness, Spatial Impresion, }\end{array}$ & 17,9 & 18,7 & 32,8 & 30,6 \\
Diffusion & & & & \\
\hline Bass reproduction & 14,7 & 21,4 & 29,4 & 34,4 \\
\hline Tonal Reproduction, Timbre & 16,5 & 22,4 & 30,0 & 31,1 \\
\hline Brilliance & 16,7 & 18,0 & 27,5 & 37,7 \\
\hline Echo Disturbance & 11,7 & 16,9 & 31,5 & 39,9 \\
\hline Spectral Uniformity, Balance & 19,7 & 14,2 & 32,4 & 33,6 \\
\hline Overall Acoustic Impression & 9,1 & 20,4 & 34,5 & 36,0 \\
\hline Sound Stage Imaging & 14,1 & 15,2 & 36,2 & 34,5 \\
\hline & 16,7 & 19,7 & 30,1 & 33,6 \\
\hline Mean value 1 & 17,1 & 19,6 & 29,8 & 33,5 \\
\hline $\begin{array}{l}\text { Mean value 2 (without Overall } \\
\text { Acoustic Impression ) }\end{array}$ & 29,6 & 25,8 & 36,6 & 40,0 \\
\hline Max & & & & 25,9 \\
\hline Min & & & & \\
\hline & & & & \\
\hline
\end{tabular}


The results of the impact analysis of parameters related to the reverberation time presented in Tab. 3 show that objective parameter EDT has the greatest impact on the audible distortion occurred in room, while its smallest impact is on the overall acoustic impression. Parameter $\mathrm{RT}_{10}$ has the greatest impact on speech intelligibility, while its smallest impact is on the spectral uniformity. Parameter $\mathrm{RT}_{20}$ has the greatest impact on the audibility of secondary sources in the room, and the lowest on the subjective assessment of noise volume in the room. Parameter $\mathrm{RT}_{30}$ has the greatest impact on the subjective assessment of sound definition (clarity), while its smallest impact is on the subjective assessment of the signal volume.

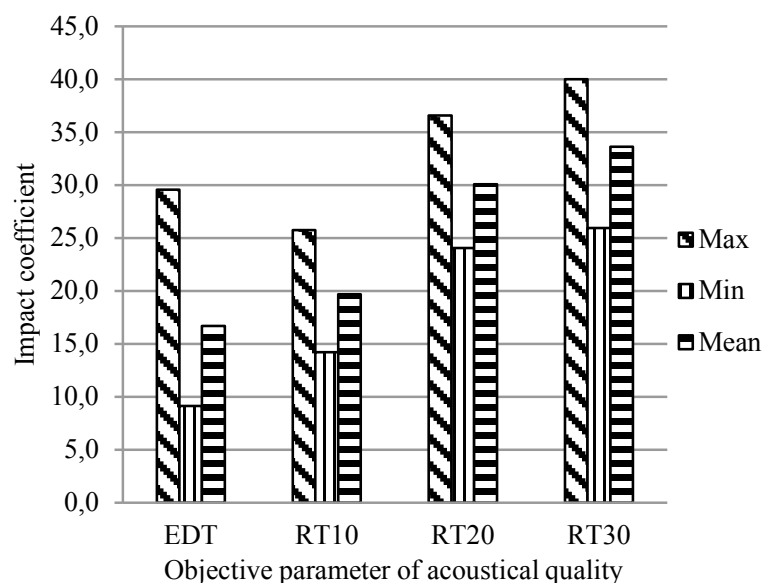

Figure 1 Impact coefficients limit values of parameters EDT, $\mathrm{RT}_{10}$, $\mathrm{RT}_{20}$ and $\mathrm{RT}_{30}$

The values of the analyzed combination of objective parameters shown in Fig. 1 indicate that the greatest impact on some of the subjective parameters has a value $\mathrm{RT}_{30}$, because even the smallest impact coefficient of parameter $\mathrm{RT}_{30}$ is almost equal to the maximum value of the impact coefficient of parameter $\mathrm{RT}_{10}$.

This fact indicates that a design of a sound control room must first of all consider the objective parameters related to the reverberation time, hence most attention should be focused on the value of parameter $\mathrm{RT}_{30}$, because this parameter has the greatest impact on the subjective assessment of room acoustic quality.

\subsection{The impact coefficients of objective parameters $C_{7}$, $\mathrm{C}_{50}, \mathrm{C}_{80}$ and $\mathrm{C}_{35}$ on the values of subjective parameters of acoustical quality}

The results of the impact analyses of parameters related to Clarity on subjective assessments of all parameters presented in Tab. 4 indicate that the parameter $\mathrm{C}_{7}$ has the greatest impact on the subjective assessment of audibility of secondary sources in the room, and the smallest impact on the overall acoustic impression. Parameter $\mathrm{C}_{50}$ has the greatest impact on the overall acoustic impression, while its smallest impact is on the sound stage imaging. Parameter $\mathrm{C}_{80}$ has the greatest impact on the subjective impression of audibility of secondary sources in the room, while its smallest impact is on the subjective assessment of reverberance in the room. Parameter $\mathrm{C}_{35}$ has the greatest impact on the assessment of the noise volume in the room, while its impact on the audibility of secondary sources is very small (coefficient with value 5,1). Notable is the fact that two objective parameters related to Clarity, $\mathrm{C}_{7}$ and $\mathrm{C}_{80}$ have the impact on the subjective assessment of audibility of secondary sources, and parameter $\mathrm{C}_{50}$ affects the overall acoustic impression.

Table 4 The impact coefficients of $\mathrm{C}_{7}, \mathrm{C}_{50}, \mathrm{C}_{80}$ and $\mathrm{C}_{35}$ on subjective

\begin{tabular}{|c|c|c|c|c|}
\hline & $\mathrm{C}_{7}$ & $\mathrm{C}_{50}$ & $\mathrm{C}_{80}$ & $\mathrm{C}_{35}$ \\
\hline Audibility of Secondary Sources & 45,3 & 17,9 & 31,7 & 5,1 \\
\hline Dynamics & 18,9 & 34,0 & 22,3 & 24,8 \\
\hline Noise volume & 17,8 & 21,1 & 20,2 & 40,8 \\
\hline Signal volume & 33,5 & 18,8 & 22,7 & 25,0 \\
\hline Intimacy (Presence) & 30,0 & 29,1 & 25,3 & 15,7 \\
\hline Distortion & 32,3 & 30,7 & 21,8 & 15,1 \\
\hline Stability of performance & 22,8 & 31,9 & 23,9 & 21,4 \\
\hline Revereberance & 30,5 & 26,3 & 17,7 & 25,5 \\
\hline Sound Definition, Clarity & 17,9 & 26,1 & 24,0 & 32,0 \\
\hline Speech Intelligibility & 33,8 & 28,8 & 23,1 & 14,4 \\
\hline $\begin{array}{l}\text { Ambience Reproduction, } \\
\text { Spaciosness, Spatial Impresion, } \\
\text { Diffusion }\end{array}$ & 23,5 & 30,2 & 26,3 & 20,0 \\
\hline Bass reproduction & 21,3 & 33,3 & 18,5 & 26,9 \\
\hline Tonal Reproduction, Timbre & 26,5 & 28,0 & 19,7 & 25,8 \\
\hline Brilliance & 22,9 & 29,6 & 23,1 & 24,5 \\
\hline Echo Disturbance & 26,5 & 31,7 & 21,3 & 20,4 \\
\hline Spectral Uniformity, Balance & 25,4 & 25,2 & 28,8 & 20,6 \\
\hline Overall Acoustic Impression & 16,9 & 43,4 & 27,2 & 12,5 \\
\hline Sound Stage Imaging & 32,8 & 15,8 & 25,8 & 25,6 \\
\hline Mean value 1 & 26,6 & 27,9 & 23,5 & 22,0 \\
\hline $\begin{array}{l}\text { Mean value } 2 \text { (without Overall } \\
\text { Acoustic Impression ) }\end{array}$ & 27,2 & 27,0 & 23,3 & 22,6 \\
\hline Max & 45,3 & 43,4 & 31,7 & 40,8 \\
\hline Min & 16,9 & 15,8 & 17,7 & 5,1 \\
\hline
\end{tabular}

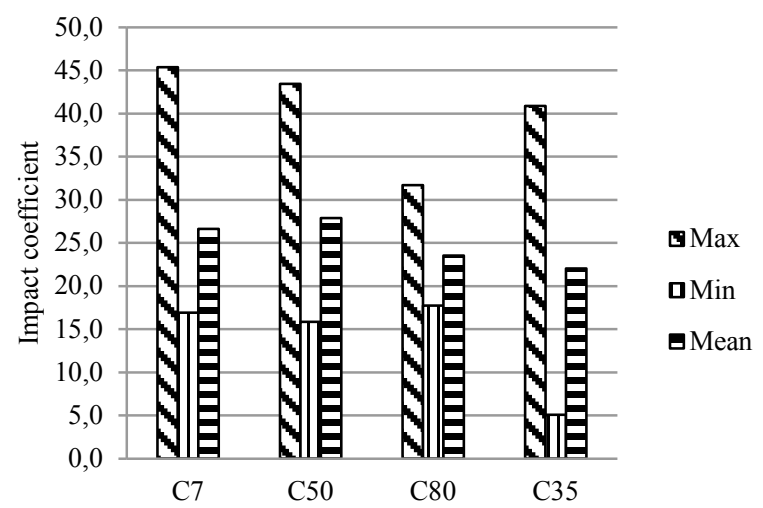

Objective parameter of acoustical quality

Figure 2 Impact coefficients limit values of parameters $C_{7}, C_{50}, C_{80}$ and $\mathrm{C}_{35}$

Results of this analyzed combination of objective parameters shows a relatively high impact of all objective parameters, with the most dominant impact of the parameter $\mathrm{C}_{50}$ on overall acoustic impression, whose value is as high as 45. The results are shown in Fig. 2.

The presented results show that the design of a sound control room, along with parameters related to the reverberation time, must properly consider and calculate a value of parameter Clarity, which accurately shows the 
relationship between the energy of direct and reflected sound.

\subsection{The impact coefficients of objective parameters EDT, $\mathrm{RT}_{10}, \mathrm{C}_{7}, \mathrm{C}_{35}$ and $\mathrm{D}$ on the values of subjective parameters of acoustical quality}

Table 5 The impact coefficients of EDT, $\mathrm{RT}_{10}, \mathrm{C}_{7}, \mathrm{C}_{35}$ and D on subjective assessments

\begin{tabular}{|l|r|r|r|r|r|}
\hline & $\mathrm{EDT}$ & $\mathrm{RT}_{10}$ & $\mathrm{C}_{7}$ & $\mathrm{C}_{35}$ & $\mathrm{D}$ \\
\hline $\begin{array}{l}\text { Audibility of Secondary } \\
\text { Sources }\end{array}$ & 26,8 & 24,0 & 35,4 & 9,0 & 4,9 \\
\hline Dynamics & 11,6 & 10,1 & 18,7 & 22,3 & 37,3 \\
\hline Noise volume & 16,4 & 12,6 & 16,2 & 36,5 & 18,3 \\
\hline Signal volume & 23,4 & 14,4 & 9,8 & 19,8 & 32,6 \\
\hline Intimacy (Presence) & 15,6 & 24,7 & 19,0 & 17,0 & 23,7 \\
\hline Distortion & 43,9 & 4,8 & 5,4 & 29,9 & 16,0 \\
\hline Stability of performance & 22,8 & 14,5 & 17,8 & 19,6 & 25,3 \\
\hline Revereberance & 20,1 & 17,8 & 18,1 & 32,0 & 12,0 \\
\hline Sound Definition, Clarity & 23,1 & 8,9 & 16,5 & 22,4 & 29,0 \\
\hline Speech Intelligibility & 19,8 & 21,4 & 9,6 & 23,8 & 25,4 \\
\hline $\begin{array}{l}\text { Ambience Reproduction, } \\
\text { Spaciosness, Spatial }\end{array}$ & 25,2 & 14,6 & 18,5 & 22,2 & 19,5 \\
Impresion, Diffusion & 25,4 & 10,3 & 17,5 & 27,8 & 19,0 \\
\hline Bass reproduction & 20,4 & 14,3 & 12,3 & 28,2 & 24,8 \\
\hline Tonal Reproduction, Timbre & 33,1 & 9,3 & 12,2 & 28,2 & 17,3 \\
\hline Brilliance & 30,6 & 11,7 & 15,4 & 28,2 & 14,1 \\
\hline Echo Disturbance & 24,7 & 16,2 & 14,6 & 16,3 & 28,2 \\
\hline $\begin{array}{l}\text { Spectral Uniformity, } \\
\text { Balance }\end{array}$ & 35,2 & 15,5 & 23,4 & 17,7 & 8,2 \\
\hline Overall Acoustic Impression & 22,2 & 16,8 & 12,7 & 15,9 & 32,4 \\
\hline Sound Stage Imaging & 24,5 & 14,5 & 16,3 & 23,2 & 21,6 \\
\hline & 23,8 & 14,5 & 15,9 & 23,5 & 22,3 \\
\hline Mean value 1 & 11,6 & 4,8 & 5,4 & 9,0 & 4,9 \\
\hline $\begin{array}{l}\text { Mean value 2 (without Overall } \\
\text { Acoustic Impression ) }\end{array}$ & 24,7 & 35,4 & 36,5 & 37,3 \\
\hline Max & & & & \\
\hline Min & 25,9 & & & & \\
\hline
\end{tabular}

In this combination of parameters, it is evident that parameter EDT has the greatest impact on the distortion in the room, while its impact is the smallest on the dynamics of the signal. Parameter $\mathrm{RT}_{10}$ has the greatest impact on intimacy (presence), and the lowest on the distortion in the room. Parameter $\mathrm{C}_{7}$ has the greatest impact on the subjective assessment of audibility of secondary sources, and the lowest on audible distortion in the room. Parameter $\mathrm{C}_{35}$ has the greatest impact on the subjective assessment of noise volume in the room, and the lowest on the audibility of secondary sources. Parameter Definition D has the greatest impact on the subjective assessment of dynamics in the room, and the lowest on the audibility of secondary sources in the room.

The biggest impact on subjective assessments of sound distortion in the room in this case has the parameter EDT, while the absolute minimal impact has the parameter $\mathrm{RT}_{10}$. All results are shown in Fig. 3.

The results indicate the need to take into account with the same significance both parameters Clarity and Definition in the room, in order to obtain the optimal solution in terms of subjective assessments of the sound control room

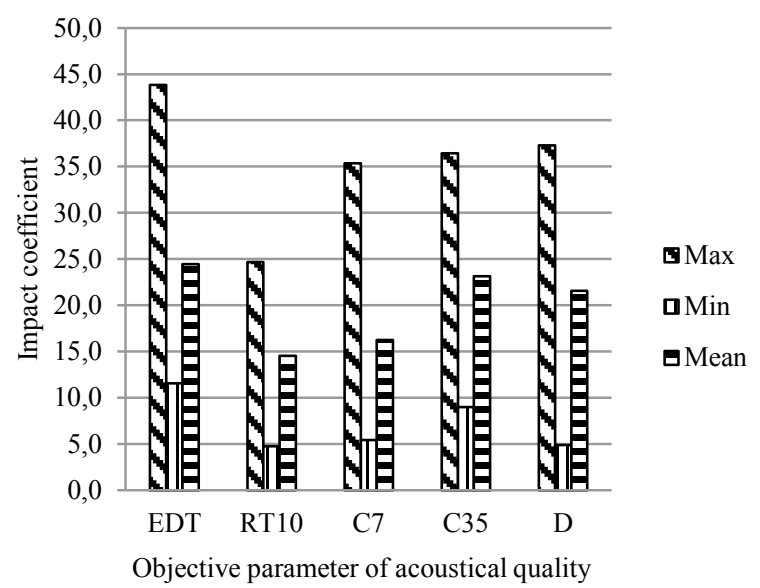

Figure 3 Impact coefficients limit values of parameters EDT, $\mathrm{RT}_{10}, \mathrm{C}_{7}$, $\mathrm{C}_{35}$ and $\mathrm{D}$

\subsection{The impact coefficients of objective parameters EDT, $\mathrm{RT}_{30}, \mathrm{C}_{50}, \mathrm{C}_{80}$ and $\mathrm{D}$ on the values of subjective parameters of acoustical quality}

Table 6 The impact coefficients of EDT, $\mathrm{RT}_{30}, \mathrm{C}_{50}, \mathrm{C}_{80}$ and $\mathrm{D}$ on subjective assessments

\begin{tabular}{|c|c|c|c|c|c|}
\hline & EDT & $\mathrm{RT}_{30}$ & $\mathrm{C}_{50}$ & $\mathrm{C}_{80}$ & $\mathrm{D}$ \\
\hline $\begin{array}{l}\text { Audibility of Secondary } \\
\text { Sources }\end{array}$ & 20,9 & 3,3 & 25,2 & 19,8 & 30,7 \\
\hline Dynamics & 21,4 & 9,6 & 19,9 & 21,4 & 27,7 \\
\hline Noise volume & 28,1 & 3,3 & 16,6 & 18,7 & 33,4 \\
\hline Signal volume & 19,7 & 9,2 & 21,5 & 21,5 & 28,1 \\
\hline Intimacy (Presence) & 23,1 & 4,3 & 23,1 & 21,1 & 28,4 \\
\hline Distortion & 22,5 & 10,2 & 21,2 & 20,8 & 25,3 \\
\hline Stability of performance & 21,9 & 5,6 & 22,0 & 20,8 & 29,7 \\
\hline Revereberance & 22,8 & 1,5 & 23,8 & 23,0 & 28,8 \\
\hline Sound Definition, Clarity & 21,3 & 3,5 & 22,6 & 24,8 & 27,8 \\
\hline Speech Intelligibility & 26,1 & 9,1 & 19,0 & 21,5 & 24,3 \\
\hline $\begin{array}{l}\text { Ambience Reproduction, } \\
\text { Spaciosness, Spatial } \\
\text { Impresion, Diffusion }\end{array}$ & 28,1 & 12,7 & 15,9 & 15,3 & 27,9 \\
\hline Bass reproduction & 22,7 & 9,0 & 21,1 & 20,2 & 27,1 \\
\hline Tonal Reproduction, Timbre & 23,0 & 12,2 & 19,0 & 21,1 & 24,8 \\
\hline Brilliance & 23,1 & 5,8 & 21,0 & 20,9 & 29,2 \\
\hline Echo Disturbance & 18,5 & 6,6 & 24,0 & 23,4 & 27,5 \\
\hline $\begin{array}{l}\text { Spectral Uniformity, } \\
\text { Balance }\end{array}$ & 24,8 & 7,0 & 21,5 & 21,5 & 25,2 \\
\hline Overall Acoustic Impres & 25,0 & 6,6 & 19,8 & 19,7 & 28,9 \\
\hline Sound Stage Imaging & 21,3 & 6,9 & 22,6 & 24,3 & 25,0 \\
\hline Mean value 1 & 23,0 & 7,0 & 21,1 & 21,1 & 27,8 \\
\hline $\begin{array}{l}\text { Mean value } 2 \text { (without Overall } \\
\text { Acoustic Impression ) }\end{array}$ & 22,9 & 7,0 & 21,2 & 21,2 & 27,7 \\
\hline Max & 28,1 & 12,7 & 25,2 & 24,8 & 33,4 \\
\hline Min & 18,5 & 1,5 & 15,9 & 15,3 & 24,3 \\
\hline
\end{tabular}

The combination of parameters with longer integration time limits and greater dynamics presented in Tab. 6 shows that, in this case, the greatest impact on subjective assessment of noise level in the room has the parameter EDT, while the least impact is on echo disturbance. Parameter $\mathrm{RT}_{30}$ generally has the greatest impact on the ambience reproduction, spaciosness, spatial impresion and diffusion, while its minimal impact is on the reverberance in the room. Parameter $\mathrm{C}_{50}$ has the greatest impact on the audibility of secondary sources, 
and the smallest on the ambience reproduction, spaciosness, spatial impresion and diffusion. Parameter $\mathrm{C}_{80}$ has the biggest impact on the clarity, and the least on ambience reproduction, spaciosness, spatial impresion and diffusion. The parameter Definition has the greatest impact on the assessment of noise volume in the room, and the least on the speech intelligibility in room.

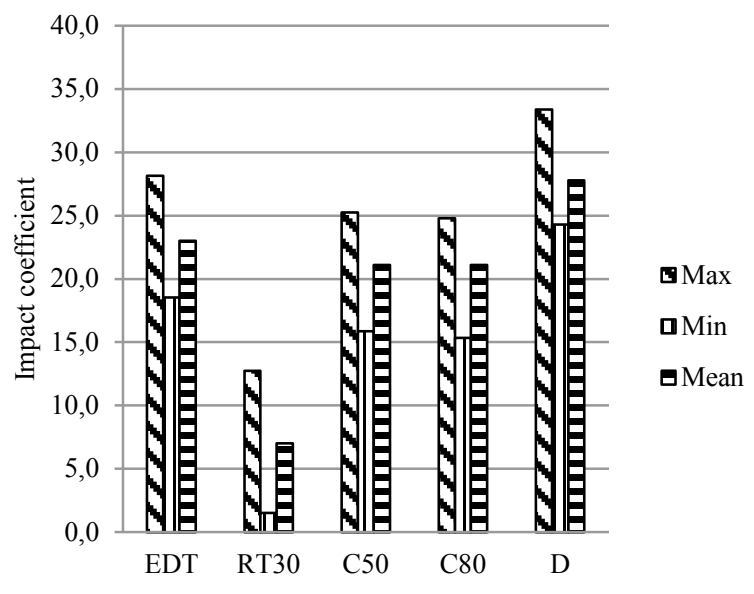

Objective parameter of acoustical quality

Figure 4 Impact coefficients limit values of parameters EDT, $\mathrm{RT}_{30}, \mathrm{C}_{50}$, $\mathrm{C}_{80}$ and $\mathrm{D}$

Absolute values of limits of objective parameters analyzed in this combination, presented in Fig. 4, show that the smallest impact on subjective evaluation has the parameter $\mathrm{RT}_{30}$, where its highest value is lower than the minimal value of any other parameter. The impact of other parameters is approximately the same.

These results show again that a design of a sound control room, in order to achieve a maximal possible subjective good impression, the parameter EDT related to reverberation time, must be considered. Also values of all other energy parameters, which show the relationship of direct sound energy and reflected sound in the room, are very important.

\subsection{The impact coefficients of objective parameters EDT, $\mathrm{C}_{7}, \mathrm{C}_{50}, \mathrm{C}_{80}$ and $\mathrm{D}$ on the values of subjective parameters of acoustical quality}

This analysis, whose results are presented in Tab. 7, shows that in this combination of parameters, parameter EDT's greatest impact is on the subjective assessment of the noise volume, while the lowest impact is on the subjective overall acoustic impression. Parameter $\mathrm{C}_{7}$ has the greatest impact on the subjective assessment of audibility of secondary sources, and the smallest on the subjective sense of distortion in the room. Parameter $\mathrm{C}_{50}$ has the greatest impact on the overall acoustic impression, while its smallest impact is on the subjective sense of the noise volume in the room. Parameter $\mathrm{C}_{80}$ has the greatest impact on the spectral uniformity, and the smallest on the assessment of audibility of secondary sources. The parameter Definition has the greatest impact on the spectral balance, and the lowest on the echo disturbance.
Table 7 The impact coefficients of EDT, $\mathrm{C}_{7}, \mathrm{C}_{50}, \mathrm{C}_{80}$ and D on subjective assessments

\begin{tabular}{|c|c|c|c|c|c|}
\hline & EDT & $\mathrm{C}_{7}$ & $\mathrm{C}_{50}$ & $\mathrm{C}_{80}$ & $\mathrm{D}$ \\
\hline $\begin{array}{l}\text { Audibility of Secondary } \\
\text { Sources }\end{array}$ & 18,7 & 12,6 & 24,1 & 14,5 & 30,1 \\
\hline Dynamics & 20,4 & 7,6 & 19,3 & 22,7 & 30,1 \\
\hline Noise volume & 30,8 & 8,2 & 16,2 & 15,8 & 29,0 \\
\hline Signal volume & 19,4 & 4,3 & 21,1 & 25,0 & 30,1 \\
\hline Intimacy (Presence) & 21,5 & 6,0 & 23,8 & 19,5 & 29,2 \\
\hline Distortion & 19,8 & 2,4 & 23,1 & 25,3 & 29,3 \\
\hline Stability of performance & 19,8 & 5,8 & 23,2 & 23,3 & 27,9 \\
\hline Revereberance & 20,0 & 6,5 & 23,8 & 22,1 & 27,7 \\
\hline Sound Definition, Clarity & 20,7 & 5,5 & 21,7 & 24,5 & 27,6 \\
\hline Speech Intelligibility & 21,0 & 6,4 & 21,0 & 22,8 & 28,8 \\
\hline $\begin{array}{l}\text { Ambience Reproduction, } \\
\text { Spaciosness, Spatial } \\
\text { Impresion, Diffusion }\end{array}$ & 23,2 & 8,0 & 17,9 & 21,6 & 29,3 \\
\hline Bass reproduction & 17,3 & 6,6 & 23,8 & 24,1 & 28,2 \\
\hline Tonal Reproduction, Tim & 18,2 & 7,5 & 21,5 & 25,0 & 27,9 \\
\hline Brilliance & 18,8 & 8,2 & 23,7 & 25,0 & 24,2 \\
\hline Echo Disturbance & 21,1 & 8,1 & 24,9 & 23,0 & 22,9 \\
\hline $\begin{array}{l}\text { Spectral Uniformity, } \\
\text { Balance }\end{array}$ & 16,1 & 8,9 & 17,9 & 26,8 & 30,4 \\
\hline Overall Acoustic Impression & 14,8 & 6,8 & 25,9 & 24,8 & 27,7 \\
\hline Sound Stage Imaging & 21,4 & 6,6 & 19,7 & 23,5 & 28,9 \\
\hline Mean value 1 & 20,2 & 7,0 & 21,8 & 22,7 & 28,3 \\
\hline $\begin{array}{l}\text { Mean value } 2 \text { (without Overall } \\
\text { Acoustic Impression ) }\end{array}$ & 20,5 & 7,0 & 21,6 & 22,6 & 28,3 \\
\hline Max & 30,8 & 12,6 & 25,9 & 26,8 & 30,4 \\
\hline Min & 14,8 & 2,4 & 16,2 & 14,5 & 22,9 \\
\hline
\end{tabular}

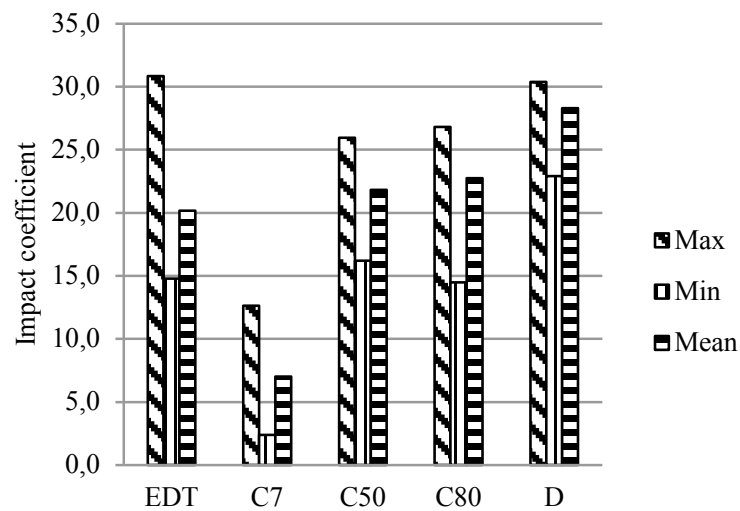

Objective parameter of acoustical quality

Figure 5 Impact coefficients limit values of parameters EDT, $C_{7}, C_{50}$, $\mathrm{C}_{80}$ and $\mathrm{D}$

The combination of absolute limit values of the parameters in this combination shows that the absolute minimal impact has the parameter $\mathrm{C}_{7}$. The other two energy parameters $C_{50}$ and $C_{80}$ have approximately the same impact, which is a bit higher than the impact of parameter EDT, while in this combination of the objective acoustical parameters the greatest impact has an objective parameter Definition D. All results are shown in Figure 5.

These results continue to confirm the thesis that during the design of the sound control room, the energy parameters Clarity and Definition have to be considered, in order to achieve the maximal possible subjective acoustical impression of the sound control room. 


\subsection{The impact coefficients of objective parameters} $\mathrm{IACC}_{\text {Early }}, \mathrm{IACC}_{\text {Late }}$ and $\mathrm{IACC}_{\text {Full }}$ on the values of subjective parameters of acoustical quality

Table 8 The impact coefficients of IACC Early $_{\text {IACC }}$ Late i IACC Full $_{\text {In }}$ on subjective assessments

\begin{tabular}{|l|r|r|r|}
\hline & IACC $_{\text {Early }}$ & IACC \\
Late & IACC $_{\text {Full }}$ \\
\hline $\begin{array}{l}\text { Audibility of Secondary } \\
\text { Sources }\end{array}$ & 78,6 & 21,4 & 0,0 \\
\hline Dynamics & 85,0 & 15,0 & 0,0 \\
\hline Noise volume & 76,8 & 23,2 & 0,0 \\
\hline Signal volume & 65,0 & 35,0 & 0,0 \\
\hline Intimacy (Presence) & 73,5 & 26,5 & 0,0 \\
\hline Distortion & 85,4 & 14,6 & 0,0 \\
\hline Stability of performance & 75,5 & 24,5 & 0,0 \\
\hline Revereberance & 70,4 & 29,6 & 0,0 \\
\hline Sound Definition, Clarity & 88,0 & 12,0 & 0,0 \\
\hline Speech Intelligibility & 61,9 & 38,1 & 0,0 \\
\hline $\begin{array}{l}\text { Ambience Reproduction, } \\
\text { Spaciosness, Spatial }\end{array}$ & 71,5 & 28,5 & 0,0 \\
Impresion, Diffusion & & & 0,0 \\
\hline Bass reproduction & 67,2 & 32,8 & 0,0 \\
\hline Tonal Reproduction, Timbre & 67,8 & 32,2 & 0,0 \\
\hline Brilliance & 79,0 & 21,0 & 0,0 \\
\hline Echo Disturbance & 79,5 & 20,5 & 0,0 \\
\hline Spectral Uniformity, Balance & 72,7 & 27,3 & 0,0 \\
\hline Overall Acoustic Impression & 56,7 & 43,3 & 0,0 \\
\hline Sound Stage Imaging & 72,8 & 27,2 & 0,0 \\
\hline & 73,7 & 26,3 & 0,0 \\
\hline Mean value 1 & 74,7 & 25,3 & 0,0 \\
\hline $\begin{array}{l}\text { Mean value 2 (without Overall } \\
\text { Acoustic Impression) }\end{array}$ & 56,7 & 12,0 & 0,0 \\
\hline Max & & & 0,0 \\
\hline Min & & & \\
\hline
\end{tabular}

Interaural cross-correlation index indicates the symmetry of the room. Interesting result is that $\mathrm{IACC}_{\mathrm{Full}}$ has no effect on subjective assessment at all. In all previous combination, there was never such a case, when one parameter has no impact at all. The results are presented in Tab. 8. Parameter IACC $\mathrm{Early}_{\text {has }}$ the greatest impact on the subjective parameter Clarity, while its smallest impact is on the overall acoustic impression. Parameter $\mathrm{IACC}_{\text {Late }}$ has the greatest impact on overall subjective acoustic impression, while its impact is the lowest on the subjective assessment of Clarity.

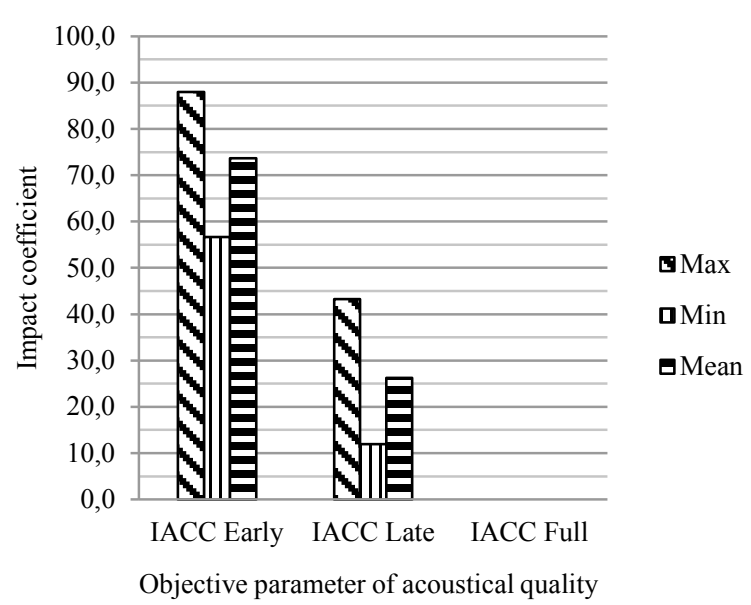

Figure 6 Impact coefficients limit values of parameters IACC $_{\text {Early, }}$ $\mathrm{IACC}_{\text {Late }}$ and $\mathrm{IACC}_{\text {Full }}$
Looking at the absolute limits shown in Figure 6 of influence of all parameters on interaural cross-correlation index, it is evident that the dominant influence for this parameter has $\mathrm{IACC}_{\text {Early, }}$ significantly less impact has IACC $_{\text {Late, }}$, while the impact of IACC $_{\text {Full }}$ is reduced to zero.

\section{Conclusion}

In this research the subjective assessments and objective tests and measurements were carried out for the same sound control rooms. The subjective assessments were carried out by members of the expert group of people who are professionals with many years of experience, dealing with the processing of and listening to music. Conditions of subjective assessment are precisely defined and each sound control room was set in line with these definitions. A general problem when assessing the acoustic quality is to properly determine the correlation between the measured objective and assessed subjective parameters of room acoustic quality. A matrix is produced as a result of the research, which included the value of objective and subjective parameters of room acoustical quality. It is not possible to directly calculate the coefficients of impact of each objective parameter on the subjective assessment, so a mathematical analysis was made with statistical Conjoint analysis method. In such a way, coefficients were estimated to describe the impact of certain objective parameters on the value of subjective acoustical quality parameters assessment. Further on, as all respondents certainly do not have the same evaluation criteria, which depends among other things on the personal preferences of each respondent, precisely defined algorithm is defined to rank individual sound control rooms. This algorithm is based on subjective ratings obtained in the study. Hence, the rooms will always be ranked in order for the best room to obtain the highest evaluation score from most respondents on all subjective parameters. When designing the sound control rooms, all parameters have to be considered all the time, not just parameters related to the reverberation time (EDT, $\mathrm{T}_{10}, \mathrm{~T}_{20}$ and $\mathrm{T}_{30}$ ), but also the parameters such as the energy parameters Clarity $\left(\mathrm{C}_{7}, \mathrm{C}_{35}, \mathrm{C}_{50}\right.$ and $\left.\mathrm{C}_{80}\right)$, Definition (D) and IACC (IACC $\mathrm{Iarly}_{\text {IACC }}$ Late and IACC $\left._{\text {Full }}\right)$ coefficients.

\section{Acknowledgements}

This research was supported by the University of Zagreb, Faculty of Electrical Engineering and Computing and Ministry of Science, Education and Sports of the Republic of Croatia (Project No. 036-0821504-2319).

\section{References}

[1] Curry, J. Understanding Conjoint Analysis in 15 Minutes. / Sawtooth Technologies, Inc., 1996.

[2] Green, P.; Srinivasan, V. Conjoint analysis in consumer research: Issues and outlook. // Journal of Consumer Research. 5, (1978). DOI: 10.1086/208721

[3] Čaklović, L. Teorija vrednovanja 2: principi, metode, primjena, predavanja 2010/11, Sveučilište u Zagrebu, PMF Matematički odjel.

[4] Brock, J. L. Acoustic Classification Using Independent Component Analysis. / Rochester, New York, May 2006. 
[5] R Installation and Administration, Version 2.15.2, 2012

[6] Chesnokov, A.; SooHoo, L. Influence of early to late energy ratios on subjective estimates of small room acoustics. // AES $105^{\text {th }}$ Convention, San Fancisco, September 1998 .

[7] Recommendation ITU-R BS.1284-1: General methods for the subjective assessment of sound quality, 1997-2003

[8] Recommendation ITU-R BS.1534-1: Method for the subjective assessment of intermediate quality level of coding systems, 2001-2003

[9] Recommendation ITU-R BS.1116-1: Methods for the subjective assessment of small impairments in audio systems including multichannel sound systems, 1994-1997

[10] Krhen, M. Optimizing Acoustical Quality Of Sound Control Room. // Ph. D. Thesis, University of Zagreb Faculty of Electrical Engineering and Computing, Zagreb, 2014.

[11] Krhen, M.; Fajt, S.; Šušković, D. The Impact Analysis of the Objective Acoustic Quality Parameters on the Subjective Assessment of Sound Control Room Reverberation. // Proceedings of the 6th Congress of the Alps Adria Acoustics Association, Graz, 2014.

[12] Rumsey, F. Subjective Assessment of the Spatial Attributes of Reproduced Sound. // AES 15th International conference, Copenhagen, 1998.

[13] Griesinger, D. General Overview of Spatial Impression, Envelopment, Localization, and Externalization. // AES 15th International conference, Copenhagen, 1998.

[14] Bodden, M. Auditory Models for Spatial Impression, Envelopment, and Localization. // AES 15th International conference, Copenhagen, 1998.

[15] Griesinger, D. Multichannel Sound Systems and Their Interaction with the Room. // AES 15th International conference, Copenhagen, 1998.

[16] Fajt, S.; Krhen, M.; Milković, M. Sound Source Influence to the Room Acoustics Quality Measurement. // Tehnički vjesnik-Technical Gazette. 22, 2(2015), pp. 487-493. DOI: 10.17559/TV-20150324110051

\section{Authors' addresses}

Marin Milković, Ph.D., Professor

University North

Trg dr. Žarka Dolinara 1, HR-48000 Koprivnica, Croatia

E-mail: marin.milkovic@unin.hr

Miljenko Krhen, Ph. D., Postdoctorand

University of Zagreb, Faculty of Electrical Engineering and Computing, Department of Electroacoustics Unska 3, HR-10000 Zagreb, Croatia

E-mail: miljenko.krhen@fer.hr

Siniša Fajt, Ph. D., Associate Professor

University of Zagreb, Faculty of Electrical Engineering and

Computing, Department of Electroacoustics

Unska 3, HR-10000 Zagreb, Croatia

E-mail: sinisa.fajt@fer.hr 